\title{
EFFECTS OF PALM KERNEL BIOCHAR AND FOOD WASTE COMPOST ON THE GROWTH OF PALM LILY (CORDYLINE FRUTICOSA), COLEUS (COLEUS SP.), AND BOAT LILY (RHOEO DISCOLOR)
}

\author{
ABDULLAH, R. ${ }^{1,2^{*}}$ - OSMAN, N. ${ }^{1}-$ YUSOFF, S. $^{3}-$ MOHD YUSOF, H. ${ }^{1}-$ ABDUL \\ HALIM, N. S. ${ }^{1}-$ MOHD ROSLI, N. S. ${ }^{1}$ \\ ${ }^{1}$ Institute of Biological Sciences, Faculty of Science, University of Malaya, 50603 Kuala \\ Lumpur, Malaysia \\ ${ }^{2}$ Centre for Research in Biotechnology for Agriculture, University of Malaya, 50603 Kuala \\ Lumpur, Malaysia \\ ${ }^{3}$ Institute of Ocean and Earth Sciences, University of Malaya, 50603 Kuala Lumpur, Malaysia \\ *Corresponding author \\ e-mail: rosazlin@um.edu.my; phone: +60-379-674-360; fax: +60-379-674-178
}

(Received 24 $4^{\text {th }}$ Jul 2020; accepted $19^{\text {th }}$ Nov 2020)

\begin{abstract}
In recent years, soil amendments have been widely used in agriculture to improve the soil quality, plant production and quality, and reduce the fertilizer usage. Thus, current study was carried out to investigate the effects of palm kernel biochar and food waste compost on soil properties, plant growth performance and physiological responses of Cordyline fruticosa, Coleus sp., and Rhoeo discolor. These plants were arranged in a randomized complete block design (RCBD) with eight treatments; control (T1), fertilizer (T2), food waste compost (T3), compost $+<20 \%$ of fertilizers (T4), biochar (T5), biochar $+<20 \%$ of fertilizers (T6), biochar + compost (T7), biochar + compost $+<20 \%$ of fertilizers (T8), with four replicates. The application of food waste compost and biochar in Coleus sp. showed the best performance concerning plant growth including the plant height $(65.75 \mathrm{~cm})$, the number of leaves (59), chlorophyll contents $\left(29.70 \mu \mathrm{mol} / \mathrm{m}^{2}\right)$, photosynthetic rate $\left(23.53 \mu \mathrm{mol} \mathrm{CO} \mathrm{C} \mathrm{s}^{-1}\right)$, stomatal conductance $\left(0.009 \mathrm{mmol} \mathrm{m}^{-2} \mathrm{~s}^{-1}\right)$, transpiration rate $\left(0.269 \mathrm{mmol} \mathrm{m}^{-2} \mathrm{~s}^{-1}\right)$, water use efficiency (WUE) (88) and total biomass $(62.50 \mathrm{~g})$. It can be concluded that the addition of compost and biochar as a soil amendment can improve soil fertility and plant growth performance.
\end{abstract}

Keywords: soil amendment, landscape plant, reduce, fertilizer, nursery

\section{Introduction}

Soil amendment is an addition of material to the soil which helps improve physical and chemical properties such as increasing soil aggregate stability, improve soil $\mathrm{pH}$, nutrient content in soil and improve aeration and drainage in soil (Shainberg et al., 1990). In recent years, soil amendments have been widely used in agriculture development to improve the soil quality, increase crop yield and plant growth performance (Chan et al., 2008). The use of agricultural wastes as soil amendments also has received attention in recent years for agronomic application (McGeehan, 2012). Biochar and compost are organic agricultural waste that undergo a transformation that facilitates their use as soil amendments. These soil amendments provide benefits most people especially farmers where the application enable them to reduce the fertilizer usage which is harmful to the environment.

Biochar technology are a technology to boost agricultural production and at the same time helps to preserve the environment (Montanarella and Lugato, 2013). Biochar is a 
charcoals that contain high carbon (C) which is more than $50 \%$ produced through pyrolysis process either with little or without oxygen (Nartey and Zhao, 2014), and it can last for a long period of time up to millions years. Biochar is similar to charcoal in terms of its shape and its black colour. Besides, biochar potentially reduces emissions compared to other biomass that will naturally lower the greenhouse gases and also have sufficient carbon absorption value (Woolf et al., 2010). The increase amount of biochar used in soil will raise the availability of major cation and phosphorus, total nitrogen and cation exchange capacity (CEC) (Lehmann et al., 2003) which ultimately will increases yield and plant growth performance. High nutrient availability for plants is a result of increased nutrition from biochar, increased nutrient retention, and changes in soil microbial dynamics (Ding et al., 2016) (Tian et al., 2016). Its long-term benefits to nutrient availability are associated with higher organic carbon stabilization along with slower nutrient release in biochar compared to commonly use organic materials (Sharma et al., 2017). The role of biochar on plant productivity improvement is influenced by the amount of biochar added as soil amendment.

In addition, compost is a nitrogen-rich organic fertilizer resulting from the decay of plant waste, food waste, and livestock faces. Matured compost can be used for soil treatment purposes, improving nutrient content in soil and planting on a small or large scale. The period of the materials to become compost is dependent on the materials used, the content of microorganisms and temperature. Food waste is widely used as a compost material because it contains high organic matter content and low heavy metals. Food waste has a wide ability for bioconversion to alternative fertilizers (Chang and Chen, 2010). This conversion requires the implementation of new technologies to recycle waste in the form of compost for use in agriculture. The addition of food waste compost to the soil has increased of the bacteria in the rhizosphere and found that this compost is composed of high carbohydrates such as fruits and vegetables and it is easy to use as a carbon source and energy by microorganisms (Lee et al., 2004). Food waste compost helps increase the nutrient content in the soil to a more compact and easily absorbed by plant for healthy growth (Chang and Chen, 2010). Food waste compost also can even improve the chemical, biological and physical levels of soil resources and reduce density and soil compression to promote the beneficial bacteria growth to the soil (Senesi and Plaza, 2007). Moreover, it can improve the ventilation, water reservoir ability to prevent the disease from the soil and the ability of food waste compost in absorb carbon has reduced the occurrence of climate change.

The ornamental plants used in this study are Cordyline fruticosa (palm lily) Coleus $s p$. (coleus), and Rhoeo discolor (boat lily). These plants are fast growing plants which become the main landscape plants used by nursery in University of Malaya and always will be replanted for the purpose of landscaping and event in campus. Hence, the current study was conducted to measure the soil properties and physiological growth responses of palm lily, coleus and boat lily using various soil amendments such as food waste compost and biochar with fertilizer and reduction of fertilizer that can be suggested to nursery of the Department of Property Management and Maintenance (JPPHB), Universiti Malaya.

\section{Materials and methods}

\section{Experimental design}

The study was conducted at the nursery of the Department of Property Management and Maintenance (JPPHB), Universiti Malaya, Malaysia for about four months of 
observation. The nursery receives a range of Photosynthetically Active Radiation (PAR) of $150-2000 \mu \mathrm{E} \mathrm{m} \mathrm{m}^{-2} \mathrm{~s}^{-1}$, relatively humidity $(\mathrm{RH}), 60-90 \%$, precipitation 5$9 \mathrm{~mm} / 0.2$ inches and temperature, $25-29{ }^{\circ} \mathrm{C}$ for 4 months starting from 29 October 2018 until 28 February 2019.

Palm lily, coleus and boat lily were grown by applying the treatments stated in Table 1. Each treatment was applied in the soil.

Table 1. List of treatments

\begin{tabular}{c|c}
\hline Treatment & Types of treatment \\
\hline Treatment & Without soil amendment (control) \\
Treatment 2 & Fertilizer \\
Treatment 3 & Food waste compost only \\
Treatment 4 & Food Waste Compost $+<20 \%$ of Fertilizers \\
Treatment 5 & Biochar only \\
Treatment 6 & Biochar $+<20 \%$ of Fertilizers \\
Treatment 7 & Biochar + Food Waste Compost \\
Treatment 8 & Biochar + Food Waste Compost $+<20 \%$ of Fertilizers \\
\hline
\end{tabular}

The experiment was arranged in a randomized complete block design (RCBD) with four replications. The amendments were mixed thoroughly into soil pots 15 days before transplanting.

\section{Preparation of planting materials}

The species studied; Cordyline fruticosa (palm lily) Coleus sp. (coleus), and Rhoeo discolor (boat lily) (Lopez-Martinez Sugey, 2018) were chosen based on their prominent role as landscape plants which are fast growing and have aesthetic values such as attractive leaf color. After two weeks of sowing, the plants were transplanted into the pots $(8 \mathrm{~cm} \times 10 \mathrm{~cm})$ size filled with soil according to the treatment. Each pot contained one plant. The ratio of the media that commonly used in the nursery is 3:2:1 which consists of topsoil, black soil organic, and sand. The topsoil refers to the top layer of about $5 \mathrm{~cm}$ to $30 \mathrm{~cm}$ from the surface of the earth. The topsoil is used to repair the soil structure by mixing or placing topsoil on the land area cultivated for agricultural purposes and supplying nutrients to the soil. The black organic soils in treatment 3, 4, 5, 6, 7 and 8 have been replaced by the biochar or compost or a mixture of both compost and biochar.

\section{Biochar and food waste compost characteristic}

Biochar used in this study is obtained from Bangi, Malaysia which is produced with $500{ }^{\circ} \mathrm{C}$ pyrolysis process. Food waste compost is obtained from Zero Waste Campaign, University Malaya which is produced by the food waste from University Malaya campus. The characteristic of biochar and compost is listed in Table 2.

\section{Data collection}

\section{Physiological parameters}

The relative chlorophyll content of the leaves was determined using a chlorophyll meter (SPAD-502 Plus, Minolta, Japan) (Aimee and Normaniza, 2014), providing a 
rapid and non-destructive approach that enables in situ measurement. The observation was made starting at 15 days after transplanting (DAT) and continued fortnightly. The photosynthetic rate, transpiration rate, and stomatal conductance were measured using a portable photosynthesis system (Li6400XT, LI-COR, USA). These parameters were measured between 11.00 am and $2.00 \mathrm{pm}$ where the plants receive optimum PAR throughout the experiment. The instantaneous water use efficiency (WUE) was determined as a ratio of photosynthetic rate (A) to transpiration rate (E) (Aimee and Normaniza, 2014).

Table 2. Chemical properties of amendment used

\begin{tabular}{c|c|c|c|c|c|c|c|c|c|c}
\hline \multirow{2}{*}{ Biochar } & \multirow{2}{*}{$\mathbf{p H}$} & $\mathbf{E C}$ & Total OC & $\mathbf{N}$ & $\mathbf{P}$ & $\mathbf{K}$ & $\mathbf{C a}$ & $\mathbf{M g}$ & $\mathbf{C u}$ \\
\cline { 3 - 10 } & & $\mathbf{( d S / m )}$ & \multicolumn{7}{|c}{$(\boldsymbol{\%})$} & $\mathbf{( p p m )}$ \\
\hline Oil palm kernel & 8.61 & 3.67 & 43.41 & 0.5 & 0.15 & 0.74 & 2.27 & 0.25 & 17.85 \\
Food waste compost & 6.60 & 2.48 & 14.34 & 2.39 & 2.82 & 0.21 & NA & 0.36 & 21.49 \\
\hline
\end{tabular}

NA $=$ Not applicable

\section{Plant height, number of leaves and total biomass}

The plant height was measured using a measuring tape and the number of leaves was counted manually every fortnightly. The total biomass was recorded after oven-drying the sample at $40{ }^{\circ} \mathrm{C}$ for $72 \mathrm{~h}$ until the weight was constant using a mass balance (accuracy of $0.01 \mathrm{~g}$ ). The dry weight of the plant was then regarded as the amount of biomass.

\section{Soil chemical analysis}

The soil $\mathrm{pH}$ in 1:2.5 (w:v) was determined after harvest by using a $\mathrm{pH}$ meter/mV with a resolution of 0.01 (HI211-01, Hanna ins., Italy). The total nitrogen (N) was determined by using the Kjeldahl method (Bremner, 1996). The sample was placed in the digestion tube with $10 \mathrm{ml}$ concentrated $\mathrm{H}_{2} \mathrm{SO}_{4}$ and a table of Kjeldahl catalyst. The sample was placed in the digestion block for $4 \mathrm{~h}$ at $330{ }^{\circ} \mathrm{C}$ or until the solution change into cloudish colour. The distillation method by collecting the distilled sample in $5 \mathrm{ml}$ of $3 \%$ boric acid until change to green colour and titration method by titrating the solution with $0.01 \mathrm{~N} \mathrm{HCL}$ until the colour change to purpled-brown colour was done for another steps to get the total nitrogen. The organic matter was determined using loss of ignition method (LOI) (Storer, 1984). The sample was placed in the crucible for heating in the oven $16 \mathrm{~h}$ at $110^{\circ} \mathrm{C}$ and heating in the muffle furnace for $6 \mathrm{~h}$ at $600{ }^{\circ} \mathrm{C}$.

\section{Data analysis}

A statistical analysis was performed using SPSS program (SPSS version 24.0). The two-way Analysis of Variance (ANOVA) was applied to determine the significant difference of eight treatment with four replication for all three different species. The post-hoc test was conducted using a Duncan's Multiple Range Test (DMRT). The correlations among the parameter studied (plant height, number of leaves, total biomass, photosynthetic rate, soil $\mathrm{pH}$, total nitrogen, and organic matter) in all treatments were also determined using Pearson's correlation. 


\section{Results}

\section{Effect of soil amendment on plant growth performance}

The application of soil amendments was positively affected the growth of palm lily, coleus and boat lily. The plant height showed significantly higher in the amendmenttreated plants than those treatments without soil amendments (control and standard media + fertilizer). Amongst the plants, coleus showed the tallest in Treatment 8 with biochar + food waste compost $+<20 \%$ fertilizer (Table 3 ).

The application of soil amendments also positively affected the number of leaves among the plant species after the four-month observation. All the species exhibited significant increment in the number of leaves, showing coleus was the highest (Table 3). In addition, Treatment 4 (food waste compost $+<20 \%$ fertilizer) showed significantly the highest increment among the treatments.

Table 3. Effect of soil amendments on the plant height and number of leaves of the species studied

\begin{tabular}{c|c|c|c|c|c|c}
\hline \multirow{2}{*}{ Treatment } & \multicolumn{3}{|c|}{ Plant height $(\mathrm{cm})$} & \multicolumn{3}{c}{ Number of leaves } \\
\cline { 2 - 7 } & Cordyline sp. & Coleus sp. & Rhoeo discolor & Cordyline sp. & Coleus sp. & Rhoeo discolor \\
\hline 1 & $24.75 \pm 2.06^{\mathrm{e}}$ & $26.75 \pm 4.11^{\mathrm{e}}$ & $19.00 \pm 4.25^{\mathrm{e}}$ & $14 \pm 2.99^{\mathrm{d}}$ & $34 \pm 2.45^{\mathrm{d}}$ & $21 \pm 1.71^{\mathrm{d}}$ \\
2 & $27.50 \pm 3.11^{\mathrm{c}}$ & $47.25 \pm 5.12^{\mathrm{c}}$ & $24.00 \pm 11.14^{\mathrm{c}}$ & $16 \pm 2.65^{\mathrm{cd}}$ & $43 \pm 5.06^{\mathrm{cd}}$ & $27 \pm 5.68^{\mathrm{cd}}$ \\
3 & $31.00 \pm 1.41^{\mathrm{ab}}$ & $64.75 \pm 9.11^{\mathrm{ab}}$ & $25.50 \pm 18.85^{\mathrm{ab}}$ & $21 \pm 2.99^{\mathrm{ab}}$ & $66 \pm 7.62^{\mathrm{ab}}$ & $40 \pm 10.21^{\mathrm{ab}}$ \\
4 & $33.50 \pm 1.91^{\mathrm{a}}$ & $58.00 \pm 4.69^{\mathrm{b}}$ & $24.75 \pm 14.94^{\mathrm{b}}$ & $25 \pm 0.58^{\mathrm{a}}$ & $70 \pm 5.35^{\mathrm{a}}$ & $42 \pm 8.54^{\mathrm{a}}$ \\
5 & $25.25 \pm 1.50^{\mathrm{d}}$ & $35.75 \pm 2.50^{\mathrm{d}}$ & $23.00 \pm 6.02^{\mathrm{d}}$ & $16 \pm 2.63^{\mathrm{c}}$ & $52 \pm 13.50^{\mathrm{c}}$ & $29 \pm 1.26^{\mathrm{c}}$ \\
6 & $28.00 \pm 1.83^{\mathrm{c}}$ & $50.75 \pm 5.91^{\mathrm{c}}$ & $22.75 \pm 13.11^{\mathrm{c}}$ & $20 \pm 2.89^{\mathrm{cd}}$ & $40 \pm 3.86^{\mathrm{cd}}$ & $25 \pm 1.26^{\mathrm{cd}}$ \\
7 & $31.50 \pm 1.29^{\mathrm{ab}}$ & $63.75 \pm 4.57^{\mathrm{ab}}$ & $23.50 \pm 18.34^{\mathrm{ab}}$ & $20 \pm 2.36^{\mathrm{b}}$ & $57 \pm 16.24^{\mathrm{b}}$ & $36 \pm 6.60^{\mathrm{b}}$ \\
8 & $33.50 \pm 0.58^{\mathrm{a}}$ & $65.75 \pm 4.03^{\mathrm{a}}$ & $26.75 \pm 17.91^{\mathrm{a}}$ & $23 \pm 0.82^{\mathrm{ab}}$ & $59 \pm 10.08^{\mathrm{ab}}$ & $37 \pm 7.48^{\mathrm{ab}}$ \\
\hline
\end{tabular}

$\mathrm{T} 1=$ control, $\mathrm{T} 2=$ standard media + fertilizer, $\mathrm{T} 3=$ food waste compost, $\mathrm{T} 4=$ food waste compost $+<20 \%$ fertilizer, T5 = biochar, T6 $=$ biochar $+<20 \%$ fertilizers, T7 $=$ biochar + food waste compost, T8 = biochar + food waste compost $+<20 \%$ fertilizer. Means followed by the same letter within a column are not significantly difference $(\mathrm{p}<0.05)$. Mean \pm Standard deviation

All plants showed significant differences in total biomass after the four-month observation. The higher total biomass indicates a good plant growth performance because the plants received the optimum requirements of nutrients. The highest total biomass was found in Treatment 8 (biochar + food waste compost $+<20 \%$ fertilizer) $(62.50 \mathrm{~g})$, followed by Treatment 3 (food waste compost) $(52.50 \mathrm{~g})$ and Treatment 7 (biochar + food waste compost) $(52.50 \mathrm{~g})$, and Treatment 4 (food waste compost $+<20 \%$ fertilizer) $(47.50 \mathrm{~g})$. Coleus showed the highest reading in total biomass among the species (Table 4).

\section{Effect of soil amendments on physiological response}

The chlorophyll content showed a positive increment after the four-month observation in all treatments. From the results, palm lily had the highest chlorophyll content between species and Treatment 3 (food waste compost) had the highest chlorophyll content among the treatment (Fig. 1a). Moreover, there was no significant interaction between species and treatment on the chlorophyll contents. 


$$
-210 \text { - }
$$

Table 4. Effect of soil amendments on the total biomass of Cordyline sp., Coleus sp. and Rhoeo discolor

\begin{tabular}{c|c|c|c}
\hline \multirow{2}{*}{ Treatment } & \multicolumn{3}{|c}{ Total biomass (g) } \\
\cline { 2 - 4 } & Cordyline sp. & Coleus sp. & Rhoeo discolor \\
\hline 1 & $11.25 \pm 6.29^{\mathrm{c}}$ & $10.00 \pm 0.00^{\mathrm{c}}$ & $13.75 \pm 7.50^{\mathrm{c}}$ \\
2 & $12.50 \pm 5.00^{\mathrm{b}}$ & $30.00 \pm 0.00^{\mathrm{b}}$ & $27.50 \pm 15.00^{\mathrm{b}}$ \\
3 & $26.25 \pm 4.78^{\mathrm{a}}$ & $52.50 \pm 17.08^{\mathrm{a}}$ & $48.75 \pm 33.26^{\mathrm{a}}$ \\
4 & $38.75 \pm 13.15^{\mathrm{a}}$ & $47.50 \pm 9.57^{\mathrm{a}}$ & $50.00 \pm 14.14^{\mathrm{a}}$ \\
5 & $10.00 \pm 0.00^{\mathrm{bc}}$ & $15.00 \pm 5.77^{\mathrm{bc}}$ & $18.75 \pm 2.50^{\mathrm{bc}}$ \\
6 & $13.75 \pm 4.79^{\mathrm{bc}}$ & $30.00 \pm 11.55^{\mathrm{bc}}$ & $17.50 \pm 9.57^{\mathrm{bc}}$ \\
7 & $23.75 \pm 4.79^{\mathrm{a}}$ & $52.50 \pm 12.58^{\mathrm{a}}$ & $37.50 \pm 9.57^{\mathrm{a}}$ \\
8 & $33.75 \pm 6.29^{\mathrm{a}}$ & $62.50 \pm 9.57^{\mathrm{a}}$ & $36.25 \pm 18.87^{\mathrm{a}}$ \\
\hline
\end{tabular}

$\mathrm{T} 1=$ control, $\mathrm{T} 2=$ standard media + fertilizer, $\mathrm{T} 3=$ food waste compost, $\mathrm{T} 4=$ food waste compost $+<20 \%$ fertilizer, $\mathrm{T} 5=$ biochar, $\mathrm{T} 6=$ biochar $+<20 \%$ fertilizers, $\mathrm{T} 7=$ biochar + food waste compost, $\mathrm{T} 8=$ biochar + food waste compost $+<20 \%$ fertilizer. Means followed by the same letter within a column are not significantly difference $(\mathrm{p}<0.05)$. Mean \pm Standard deviation

The photosynthetic rate, stomatal conductance and transpiration rate of each plant species showed much affected by different treatments. The photosynthetic rate of each plant species showed a significant difference after the four-month observation where Treatment 4 (food waste compost $+<20 \%$ fertilizer) had a highest photosynthetic rate among treatments. Each species showed a significant interaction effect on photosynthetic rate where Treatment 4 (food waste compost $+<20 \%$ fertilizer) in coleus was the significant highest reading among the species.

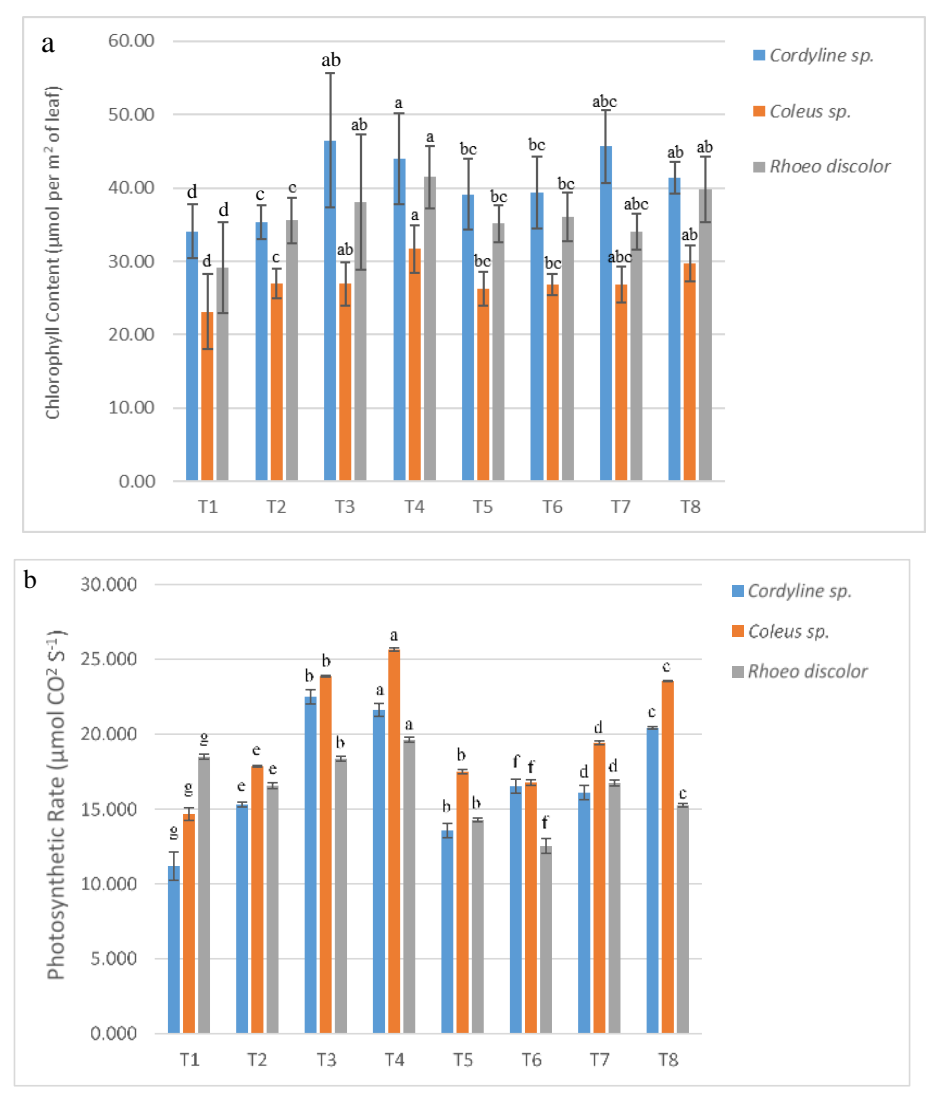



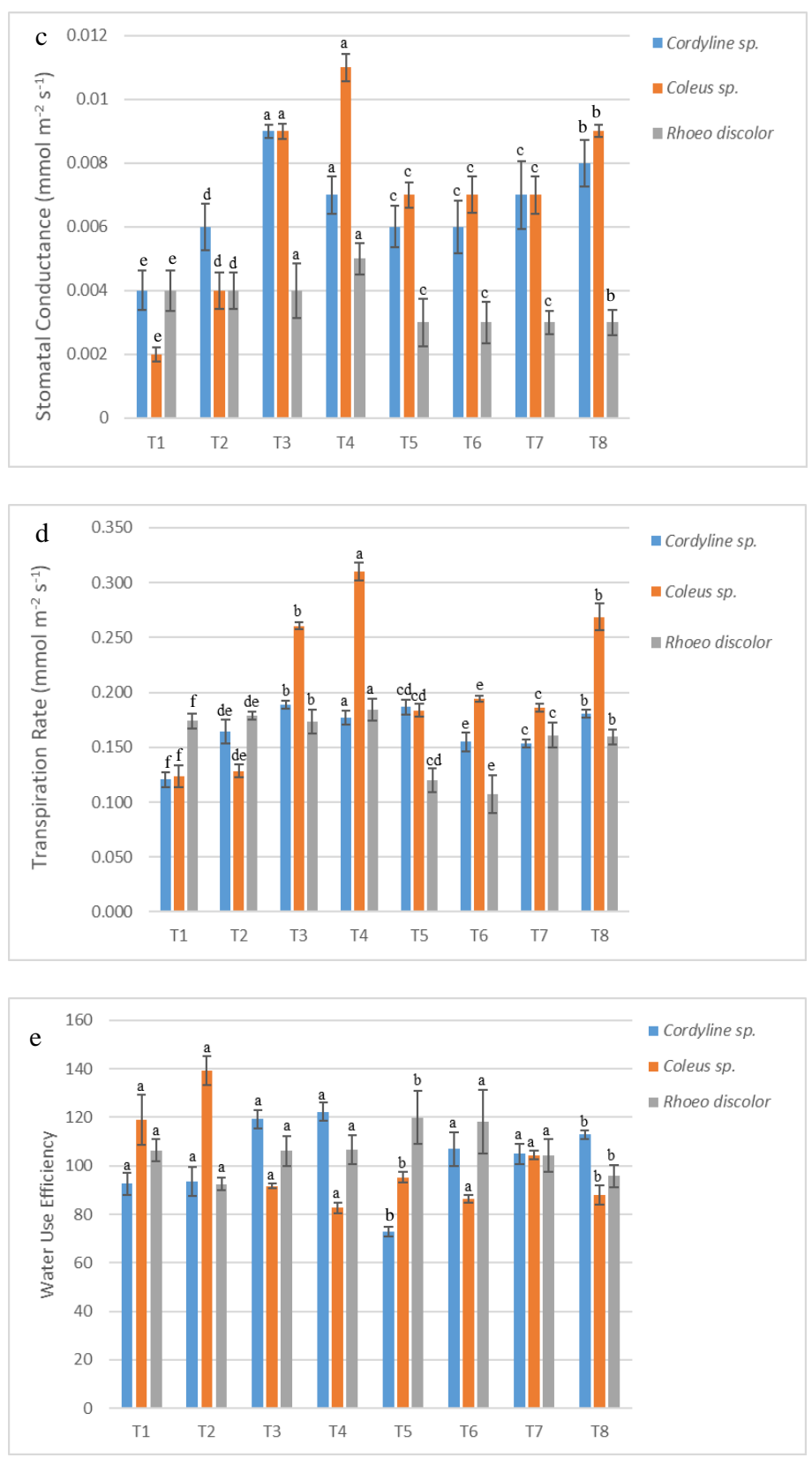

Figure 1. Effect of different treatments on (a) chlorophyll content (b) photosynthetic rate, (c) stomatal conductance, $(d)$ transpiration rate and $(e)$ water use efficiency after the four-month observation for each plant species. Each data item represents the mean of replicates and the vertical bar represents the standard deviation. $T 1=$ control, $T 2=$ standard media + fertilizer, $T 3=$ food waste compost, T4 = food waste compost $+<20 \%$ fertilizer, T5 = biochar, T6 = biochar $+<20 \%$ fertilizers, $T 7=$ biochar + food waste compost, $T 8=$ biochar + food waste compost $+<20 \%$ fertilizer. Means followed by the same letter are not significantly difference $(p<0.05)$

The increasing in stomatal conductance indicated the good and well plant characteristics meanwhile high transpiration rate indicated the excessive water discharge rates at plants. The results showed that there was a significant species and treatment effect on the stomatal conductance and also the transpiration rate. The results indicate that Treatment 4 (food waste compost $+<20 \%$ fertilizer) in coleus lost the 
greatest amount of water through high transpiration and stomatal conductance, followed by Treatment 3 (food waste compost) and Treatment 8 (biochar + food waste compost $+<20 \%$ fertilizer) (Fig. $1 c, d$ ). From the results, a significantly higher water use efficiency (WUE) was found in the Treatment 2 (fertilizer) in coleus while the lowest reading was recorded for the Treatment 5 (biochar) in palm lily (Fig. 1e). The WUE is a response between the photosynthetic and transpiration rates, where a high WUE was indicated by a high photosynthetic and low transpiration rate.

\section{Effect of soil amendment on soil ph, total nitrogen and organic matter for each plant species}

The overall plants species in all treatments have a significant increment in soil $\mathrm{pH}$ after the four-month observation. Treatment 5 (biochar) in both coleus and boat lily showed the highest reading (7.83) in soil $\mathrm{pH}$ respectively. The results also showed that there were significantly species and treatment effect on the soil $\mathrm{pH}$. Based on the results, there were a significant species on the soil $\mathrm{pH}$ which are coleus was the significant highest among the species.

The application of soil amendment gives a significant increment reading in Total Nitrogen which lead by Treatment 4 (food waste compost $+<20 \%$ fertilizers) in palm lily meanwhile the least significant total nitrogen was in Treatment 5 (biochar) for coleus. The results in Table 5 also showed that there was no significant treatment and species effect on the total nitrogen.

Table 5. Effect of soil amendments on the soil $p H$ and total nitrogen for Cordyline sp., Coleus sp. and Rhoeo discolor

\begin{tabular}{c|c|c|c|c|c|c}
\hline Treatment & \multicolumn{3}{|c|}{ Soil $\mathrm{pH}$} & \multicolumn{3}{c}{ Total nitrogen (\%) } \\
\hline & Cordyline sp. & Coleus sp. & Rhoeo discolor & Cordyline sp. & Coleus sp. & Rhoeo discolor \\
\hline 1 & $7.56 \pm 0.09^{\mathrm{bc}}$ & $7.61 \pm 0.16^{\mathrm{bc}}$ & $7.61 \pm 0.16^{\mathrm{bc}}$ & $0.29 \pm 0.20^{\mathrm{b}}$ & $0.18 \pm 0.01^{\mathrm{b}}$ & $0.40 \pm 0.00^{\mathrm{b}}$ \\
2 & $7.36 \pm 0.10^{\mathrm{de}}$ & $7.45 \pm 0.08^{\mathrm{de}}$ & $7.45 \pm 0.09^{\mathrm{de}}$ & $0.29 \pm 0.01^{\mathrm{ab}}$ & $0.29 \pm 0.05^{\mathrm{ab}}$ & $0.13 \pm 0.02^{\mathrm{ab}}$ \\
3 & $7.21 \pm 0.13^{\mathrm{e}}$ & $7.32 \pm 0.10^{\mathrm{e}}$ & $7.32 \pm 0.10^{\mathrm{e}}$ & $0.50 \pm 0.21^{\mathrm{a}}$ & $0.20 \pm 0.07^{\mathrm{a}}$ & $0.33 \pm 0.18^{\mathrm{a}}$ \\
4 & $7.30 \pm 0.25^{\mathrm{cd}}$ & $7.68 \pm 0.17^{\mathrm{dd}}$ & $7.68 \pm 0.17^{\mathrm{cd}}$ & $0.43 \pm 0.01^{\mathrm{a}}$ & $0.37 \pm 0.03^{\mathrm{a}}$ & $0.27 \pm 0.23^{\mathrm{a}}$ \\
5 & $7.61 \pm 0.23^{\mathrm{a}}$ & $7.83 \pm 0.22^{\mathrm{a}}$ & $7.83 \pm 0.22^{\mathrm{a}}$ & $0.26 \pm 0.11^{\mathrm{ab}}$ & $0.11 \pm 0.04^{\mathrm{ab}}$ & $0.40 \pm 0.17^{\mathrm{ab}}$ \\
6 & $7.54 \pm 0.27^{\mathrm{cd}}$ & $7.56 \pm 0.10^{\mathrm{cd}}$ & $7.56 \pm 0.10^{\mathrm{cd}}$ & $0.24 \pm 0.16^{\mathrm{ab}}$ & $0.30 \pm 0.02^{\mathrm{ab}}$ & $0.20 \pm 0.02^{\mathrm{ab}}$ \\
7 & $7.62 \pm 0.23^{\mathrm{ab}}$ & $7.76 \pm 0.14^{\mathrm{ab}}$ & $7.76 \pm 0.14^{\mathrm{ab}}$ & $0.28 \pm 0.01^{\mathrm{ab}}$ & $0.26 \pm 0.09^{\mathrm{ab}}$ & $0.39 \pm 0.14^{\mathrm{ab}}$ \\
8 & $7.37 \pm 0.12^{\mathrm{d}}$ & $7.49 \pm 0.15^{\mathrm{d}}$ & $7.45 \pm 0.24^{\mathrm{d}}$ & $0.37 \pm 0.13^{\mathrm{ab}}$ & $0.14 \pm 0.01^{\mathrm{ab}}$ & $0.33 \pm 0.03^{\mathrm{ab}}$ \\
\hline
\end{tabular}

$\mathrm{T} 1=$ control, $\mathrm{T} 2=$ standard media + fertilizer, $\mathrm{T} 3=$ food waste compost, $\mathrm{T} 4=$ food waste compost $+<20 \%$ fertilizer, T5 = biochar, T6 $=$ biochar $+<20 \%$ fertilizers, T7 $=$ biochar + food waste compost, $\mathrm{T} 8$ = biochar + food waste compost $+<20 \%$ fertilizer. Means followed by the same letter within a column are not significantly difference $(\mathrm{p}<0.05)$. Mean \pm Standard deviation

In general, organic matter was affected by the soil amendments throughout the observation. Based on the result, the significant highest organic matter was found in Treatment 8 (biochar + food waste compost $+<20 \%$ fertilizers) in coleus $(2.13 \%)$ and the least organic matter was in Treatment 1 (control) in boat lily $(0.53 \%)$. The results also showed that there was a palm lily has the highest significant of organic matter 


$$
-213-
$$

among the species $(1.98 \%)$. Besides, there was no significant interaction between species and treatment effect on soil organic matter (Table 6).

Table 6. Effect of soil amendments on organic matter for Cordyline sp., Coleus sp. and Rhoeo discolor

\begin{tabular}{c|c|c|c}
\hline \multirow{2}{*}{ Treatment } & \multicolumn{3}{|c}{ Organic matter $(\%)$} \\
\cline { 2 - 4 } & Cordyline sp. & Coleus sp. & Rhoeo discolor \\
\hline 1 & $0.99 \pm 0.53^{\mathrm{bc}}$ & $0.71 \pm 0.01^{\mathrm{bc}}$ & $0.53 \pm 0.08^{\mathrm{bc}}$ \\
2 & $0.62 \pm 0.19^{\mathrm{c}}$ & $0.56 \pm 0.33^{\mathrm{c}}$ & $0.58 \pm 0.37^{\mathrm{c}}$ \\
3 & $1.58 \pm 0.22^{\mathrm{ab}}$ & $1.05 \pm 0.02^{\mathrm{ab}}$ & $1.25 \pm 0.50^{\mathrm{ab}}$ \\
4 & $1.78 \pm 0.47^{\mathrm{a}}$ & $1.67 \pm 0.24^{\mathrm{a}}$ & $1.15 \pm 0.50^{\mathrm{a}}$ \\
5 & $1.78 \pm 0.47^{\mathrm{ab}}$ & $1.07 \pm 0.62^{\mathrm{ab}}$ & $0.67 \pm 0.25^{\mathrm{ab}}$ \\
6 & $1.30 \pm 0.30^{\mathrm{ab}}$ & $1.52 \pm 0.12^{\mathrm{ab}}$ & $0.91 \pm 0.13^{\mathrm{ab}}$ \\
7 & $1.98 \pm 0.40^{\mathrm{a}}$ & $1.93 \pm 0.45^{\mathrm{a}}$ & $1.00 \pm 0.62^{\mathrm{a}}$ \\
8 & $1.85 \pm 0.64^{\mathrm{a}}$ & $2.13 \pm 1.02^{\mathrm{a}}$ & $0.90 \pm 0.60^{\mathrm{a}}$ \\
\hline
\end{tabular}

$\mathrm{T} 1=$ control, $\mathrm{T} 2$ = standard media + fertilizer, $\mathrm{T} 3=$ food waste compost, $\mathrm{T} 4=$ food waste compost $+<20 \%$ fertilizer, T5 = biochar, T6 $=$ biochar $+<20 \%$ fertilizers, T7 $=$ biochar + food waste compost, $\mathrm{T} 8=$ biochar + food waste compost $+<20 \%$ fertilizer. Means followed by the same letter within a column are not significantly difference $(\mathrm{p}<0.05)$. Mean \pm standard deviation

\section{Correlation between photosynthetic rate and plant height}

The photosynthetic rate and plant height were significantly correlated $(\mathrm{R}=0.5536$; Fig. 2), the higher the photosynthetic rate, the higher the plant heights.

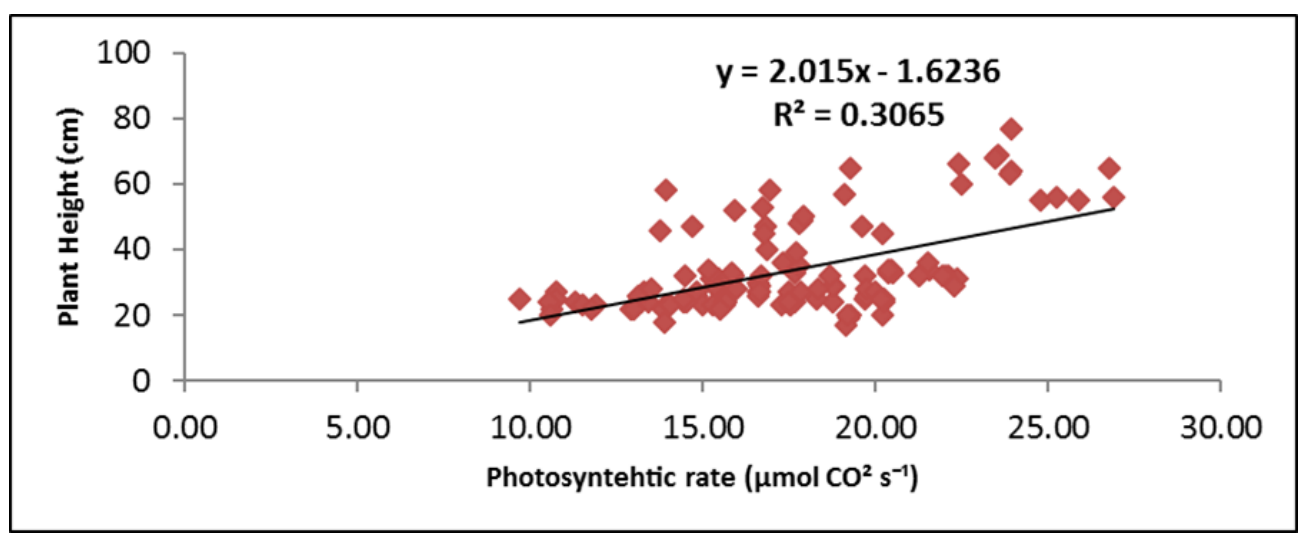

Figure 2. Correlation between photosynthetic rate and plant height

\section{Correlation between plant growth and soil properties}

The correlation studies between plant growth and soil properties parameters showed that the plant height was significantly correlated with the number of leaves, total biomass and organic matter (Table 7). However, there was no correlation was observed between plant height with both soil $\mathrm{pH}$ and total nitrogen. In addition, the number of leaves is significantly correlated with total biomass and the number of leaves only meanwhile the total biomass only has a significant correlation with soil $\mathrm{pH}$. 


$$
-214-
$$

Table 7. Correlation analysis deduced between plant growth and soil properties using Pearson's correlation

\begin{tabular}{c|c|c|c|c|c|c}
\hline Parameter & Plant height & Number of leaves & Total biomass & Soil pH & Total nitrogen & Organic matter \\
\hline Plant height & - & $0.834^{* *}$ & $0.571^{* *}$ & -0.024 & -0.019 & $0.255^{*}$ \\
Number of leaves & & - & $0.615^{* *}$ & 0.118 & -0.078 & 0.078 \\
Total biomass & & & - & $-0.203^{*}$ & 0.111 & 0.128 \\
Soil pH & & & & - & -0.174 & -0.072 \\
Total nitrogen & & & & & - & 0.114 \\
Organic matter & & & & & & - \\
\hline
\end{tabular}

${ }^{* *}$ Significant at 0.01 level

*Significant at 0.05 level

\section{Discussion}

In general, the plant growth and soil properties were much affected by the soil amendments in a four-month observation. The best treatment was found to be combination of biochar and food waste compost and the best plant growth was exhibited by coleus.

In monitoring the growth performance of each plant species, several growth characteristics were observed such as plant height, number of leaves and total biomass. The growth performance showed that coleus. in Treatment 8 (biochar + food waste compost $+<20 \%$ ) and Treatment 4 (food waste compost $+<20 \%$ of fertilizers) exhibited the highest reading in plant height and number of leaves. The compost effects have succeeded in increasing plant growth due to its higher cation-exchange capacity (CEC) and base saturation (BS) as well as providing Nitrogen (N) and Phosphorus (P) which useful for plant growth. In addition, cation and anion which contained in food waste compost treatments have an imbalance contents between $\mathrm{NH}_{4}{ }^{+}$and $\mathrm{NO}_{3}{ }^{-}$which may be a potential cause for increasing the plant growth (Schulz and Glaser, 2012).

Other than that, the total biomass of coleus in Treatment 8 (biochar + food waste compost $+<20 \%$ of fertilizers treatment) was the highest reading among the species. This was in line with (Schulz et al., 2013), in which the addition of composted biochar significantly increased the plant height and above-ground biomass. Biochar can act as a soil conditioner that increases the soil's nutrient deposition capacity (Miranda et al., 2017), enhances and maintains nutrients in the soil, hence will improve the plant growth. In addition, the potential of biochar as a source of nutrients can be depending on feedstock and temperature of pyrolysis where the lower pyrolysis temperatures may increase the availability of nitrogen $(\mathrm{N})$ and phosphorus (P) (Yuan et al., 2019) besides reduces the $\mathrm{N}_{2} \mathrm{O}$ emissions, while higher pyrolysis temperatures may increase potassium (K) availability (Ding et al., 2016). Furthermore, nutrients in compost contribute to increase in stem height, thus enhance the plant growth performance (Mensah and Frimpong, 2018). Despite a low reading of plant height in boat lily, it showed considerable increased in number of leaves especially in Treatment 3 (food waste compost) and Treatment 4 (food waste compost + less $20 \%$ of fertilizers) because of increase in nitrogen contents in these treatments.

The highest reading chlorophyll content was shown by coleus in Treatment 3 (food waste compost). Besides, the right combination of biochar, compost, and fertilizer significantly increased the total chlorophyll content of the species studied compared to the use of fertilizers alone. The use compost alone increased the chlorophyll content but by the combination of biochar, compost and fertilizer also increased the chlorophyll 
content for each species. The organic amendment in soil increases the nutrients and water content in soil, thus restricting in increase of chlorophyll content and the plant age (Agegnehu et al., 2016).

The stomata play an important role in the process of photosynthesis and transpiration. Stomata is a small pore beneath the surface of the leaves which mostly allow air $\left(\mathrm{CO}_{2}\right)$ to enter and allow water $\left(\mathrm{H}_{2} \mathrm{O}\right)$ and oxygen $\left(\mathrm{O}_{2}\right)$ to come out. Photosynthesis is a process that plants produce food and energy. Based on the results in this study, the coleus has large pores which cause photosynthetic and transpiration to occur more efficiently. The midday stomatal closure occurs due to the effects of low atmospheric humidity as well as from water pressure and high temperature. Stomata tend to adjust regularly to maintain photosynthesis to transpiration ratio is and then increased the water use efficiency (WUE) (Noor and Harun, 2004).

In addition, the highest increment of photosynthetic rate and transpiration rate in coleus suggested that its roots absorb water and nutrients directly from the soil more efficiently as compared to other species. coleus has the highest reading water use efficiency (WUE) shows the ability of the species to store the water. The highest water use efficiency (WUE) in palm lily compared to coleus and boat lily may be caused by mesophyll ratio of surface cells to the surface of the leaves might increase the WUE by increasing photosynthesis more than an increased transpiration (Noor and Harun, 2004). Furthermore, plant mortality will result in the reduction of both rates of photosynthesis and transpiration. The old leaves have a low rate of photosynthesis and transpiration compared to the younger leaves (Mensah and Frimpong, 2018). Thus, the application of biochar and compost with fertilizer contributes to the higher chlorophyll content and number of leaves, consequently result in higher of photosynthetic rate (Hidayati and Anas, 2016).

This study found that the soil $\mathrm{pH}$ of all treatments and species mostly tends to be neutral around 7-7.5 after four months of observation. The application of soil amendments showed the decrement reading in soil $\mathrm{pH}$, which may be due to the acidic materials produced from the oxidation and decomposition of organic matter in the soil (Senesi and Plaza, 2007; Dias et al., 2010). The formation of the acidic functional groups can neutralize alkalinity and eventually decrease soil pH (Xiang-Hong et al., 2012).

Accumulation of high Soil Organic Carbon (SOC) in biochar can increase total nitrogen and finally, resulting in increases of crop production. Moreover, both biochar and compost have significantly contributed higher total nitrogen after harvest compare to control (Schulz et al., 2013) but too much of total nitrogen also contributed in slowing the maturity of the plant. In addition, loss of the total nitrogen on the soil may be caused by several factors such as the use of the plant itself or microorganisms and also carried by rainwater (El-Sharkawi, 2012).

Soil organic matter is a major factor in determining the fertility of soil. It supplies energy for microbial biomass activity (Schnürer et al., 1985), provides nutrients for crops and improves the physical properties of the soil (Six et al., 2002). Organic matter in soil can be affected by treatments where higher values can be indicators of improving soil fertility. Biochar has the potential to affect microbial biomass and composition and the microbes are also able to change the properties of biochar (Lehmann et al., 2011). The porous nature of biochar because of its high surface area and its ability to adsorb soluble organic matter and inorganic nutrients, biochar provides a suitable habitat for 
microbes (Lehmann et al., 2011). In addition, high amount of organic matter in compost increased organic carbon in the soil.

The photosynthetic rate and plant height has shown a positive correlation indicating that the increases of the carbon dioxide absorption and light trapping have contributed to the higher photosynthetic rate and then enhance the plant height. Chlorophyll green pigments in chloroplasts of the leaves of the plants are one of the photosynthetic pigments that play a key role in absorbing solar energy (Vasconcelos et al., 2017).

\section{Conclusions}

The application of soil amendments can improve soil fertility and plant growth performance together with fertilizer. In this study, the application of food waste compost and biochar in coleus showed the best performance in the plant growth including the number of leaves, chlorophyll contents, photosynthetic rate, stomatal conductance, transpiration rate, water use efficiency (WUE) and total biomass.

Similarly, higher values of soil $\mathrm{pH}$, amounts of total nitrogen, and organic matter content were observed in food waste compost and biochar treatment. It is evident that the combination effect of biochar and food waste compost either biochar alone or compost alone contributed the positive effect on plant growth performance as well as soil properties. Based on the overall result, the use of food waste compost and biochar have potential to be used to improve the quality of soil.

Acknowledgements. The authors thank the University of Malaya for financial support by UM Living Lab Grant Programme - SUS (Sustainability Science) (LL036-18SUS) and Knowledge Transfer Programme (KTP) grant (MRUN2019-2A).

\section{REFERENCES}

[1] Agegnehu, G., Nelson, P. N., Bird, M. I. (2016): The effects of biochar, compost and their mixture and nitrogen fertilizer on yield and nitrogen use efficiency of barley grown on a Nitisol in the highlands of Ethiopia. - Science of the Total Environment 569: 869879 .

[2] Aimee, H., Normaniza, O. (2014): Physiological responses of Melastoma malabathricum at different slope orientations. - J. Trop. Plant Physiol 6: 10-22.

[3] Bremner, J. M. (1996): Nitrogen-Total. - In: Sparks, D. L. et al. (eds.) Methods of Soil Analysis: Part 3 Chemical Methods. SSSA, Madison, WI, pp. 1085-1121.

[4] Chan, K. Y., Van Zwieten, L., Meszaros, I., Downie, A., Joseph, S. (2008): Agronomic values of greenwaste biochar as a soil amendment. - Soil Research 45: 629-634.

[5] Chang, J. I., Chen, Y. (2010): Effects of bulking agents on food waste composting. Bioresource Technology 101: 5917-5924.

[6] Dias, B. O., Silva, C. A., Higshikawa, F. S., Roig, A., Sanchez-Monedero, M. A. (2010): Use of biochar as bulking agent for the composting of poultry manure: effect on organic matter degradation and humification. - Bioresource Technology 101: 1239-1246.

[7] Ding, Y., Liu, Y., Liu, S., Li, Z., Tan, X., Huang, X., Zeng, G., Zhou, L., Zheng, B. (2016): Biochar to improve soil fertility. A review. - Agronomy for Sustainable Development 36: 36.

[8] El-Sharkawi, H. M. (2012): Effect of nitrogen sources on microbial biomass nitrogen under different soil types. - ISRN Soil Science. https://doi.org/10.5402/2012/310727. 
[9] Hidayati, N., Anas, I. (2016): Photosynthesis and transpiration rates of rice cultivated under the system of rice intensification and the effects on growth and yield. - HAYATI Journal of Biosciences 23: 67-72.

[10] Lee, J.-J., Park, R.-D., Kim, Y.-W., Shim, J.-H., Chae, D.-H., Rim, Y.-S., Sohn, B.-K., Kim, T.-H., Kim, K.-Y. (2004): Effect of food waste compost on microbial population, soil enzyme activity and lettuce growth. - Bioresource Technology 93: 21-28.

[11] Lehmann, J., Da Silva, J. P., Steiner, C., Nehls, T., Zech, W., Glaser, B. (2003): Nutrient availability and leaching in an archaeological Anthrosol and a Ferralsol of the Central Amazon basin: fertilizer, manure and charcoal amendments. - Plant and Soil 249: 343357.

[12] Lehmann, J., Rillig, M. C., Thies, J., Masiello, C. A., Hockaday, W. C., Crowley, D. (2011): Biochar effects on soil biota-a review. - Soil Biology and Biochemistry 43: $1812-1836$.

[13] Lopez-Martinez Sugey, G.-M. E. G., Lopez, Y. C. I., Lara Corona, V. H., LagunasRivera, S. (2018): Rhoeo discolor: a medicinal plant with phytoremediation potential. Int. J. Adv. Res. 6: 763-770.

[14] McGeehan, S. L. (2012): Impact of waste materials and organic amendments on soil properties and vegetative performance. - Applied and Environmental Soil Science. https://doi.org/10.1155/2012/907831.

[15] Mensah, A. K., Frimpong, K. A. (2018): Biochar and/or compost applications improve soil properties, growth, and yield of maize grown in acidic rainforest and coastal savannah soils in Ghana. - International Journal of Agronomy. https://doi.org/10.1155/2018/6837404.

[16] Miranda, N. D. O., Pimenta, A. S., Silva, G. G. C. D., Oliveira, E., Mota, M., Carvalho, M. A. B. D. (2017): Biochar as soil conditioner in the succession of upland rice and cowpea fertilized with nitrogen. - Revista Caatinga 30: 313-323.

[17] Montanarella, L., Lugato, E. (2013): The application of biochar in the EU: challenges and opportunities. - Agronomy 3: 462-473.

[18] Nartey, O. D., Zhao, B. (2014): Biochar preparation, characterization, and adsorptive capacity and its effect on bioavailability of contaminants: an overview. - Advances in Materials Science and Engineering. https://doi.org/10.1155/2014/715398.

[19] Noor, M. R. M., Harun, M. H. (2004): Importance of water use efficiency (WUE) in oil palm productivity. - Oil Palm Bulletin 2004: 24-30.

[20] Schulz, H., Glaser, B. (2012): Effects of biochar compared to organic and inorganic fertilizers on soil quality and plant growth in a greenhouse experiment. - Journal of Plant Nutrition and Soil Science 175: 410-422.

[21] Schulz, H., Dunst, G., Glaser, B. (2013): Positive effects of composted biochar on plant growth and soil fertility. - Agronomy for Sustainable Development 33: 817-827.

[22] Schurer, J., Clarholm, M., Rosswall, T. (1985): Microbial biomass and activity in an agricultural soil with different organic matter contents. - Soil Biology and Biochemistry 17: 611-618.

[23] Senesi, N., Plaza, C. (2007): Role of humification processes in recycling organic wastes of various nature and sources as soil amendments. - Clean; Soil, Air, Water 35: 26-41.

[24] Shainberg, I., Warrington, D., Rengasamy, P. (1990): Water quality and PAM interactions in reducing surface sealing. - Soil Science 149: 301-307.

[25] Sharma, A., Saha, T. N., Arora, A., Shah, R., Nain, L. (2017): Efficient Microorganism compost benefits plant growth and improves soil health in calendula and marigold. Horticultural Plant Journal 3 67-72.

[26] Six, J., Feller, C., Denef, K., Ogle, S., De Moraes Sa, J. C., Albrecht, A. (2002): Soil organic matter, biota and aggregation in temperate and tropical soils. - Effects of notillage. - Agronomie 22: 755-775

[27] Storer, D. A. (1984): A simple high sample volume ashing procedure for determination of soil organic matter. - Communications in Soil Science and Plant Analysis 15: 759-772. 
[28] Tian, Q., He, H., Cheng, W., Bai, Z., Wang, Y., Zhang, X. (2016): Factors controlling soil organic carbon stability along a temperate forest altitudinal gradient. - Scientific Reports 6: 1-9.

[29] Vasconcelos, A. C. F. D., Chaves, L. H. G., Gheyi, H. R., Fernandes, J. D., Tito, G. A. (2017): Crambe growth in a soil amended with biochar and under saline irrigation. Communications in Soil Science and Plant Analysis 48: 1291-1300.

[30] Woolf, D., Amonette, J. E., Street-Perrott, F. A., Lehmann, J., Joseph, S. (2010): Sustainable biochar to mitigate global climate change. - Nature Communications 1: 1-9.

[31] Xiang-Hong, L., Feng-Peng, H., Xing-Chang, Z. (2012): Effect of biochar on soil aggregates in the Loess Plateau: results from incubation experiments. - International Journal of Agriculture and Biology 4(6): 975-979.

[32] Yuan, P., Wang, J., Pan, Y., Shen, B., Wu, C. (2019): Review of biochar for the management of contaminated soil: preparation, application and prospect. - Science of the Total Environment 659: 473-490. 